\title{
COMPARATIVE STUDY OF BUTANOLIC AND ETHANOLIC EXTRACTS OF TRIBULUS TERRESTRIS FRUITS IN 2,3,7,8-TETRACHLORODIBENZO-P-DIOXIN-INDUCED HEPATOTOXICITY IN RATS
}

\author{
RAJESWARI HARI ${ }^{1 *}$, MURALIDHARAN P² \\ ${ }^{1}$ Department of Biotechnology, Dr. M.G.R. Educational and Research Institute, Chennai, Tamil Nadu, India. ${ }^{2}$ Department of Pharmacology \\ and Toxicology, C.L. Baid Metha College of Pharmacy, Chennai, Tamil Nadu, India. Email: rajihar@gmail.com
}

Received: 29 January 2018, Revised and Accepted: 10 March 2018

\section{ABSTRACT}

Objective: To compare hepatoprotective activity of ethanol and butanol fraction of Tribulus terrestris fruits against 2,3,7,8-tetrachlorodibenzo-pdioxin (TCDD)-induced hepatic damage in albino rats.

Methods: The degree of liver protection was assessed in terms of biochemical parameters, liver marker enzymes, and lipid peroxidation (LPO) in drug-treated and TCDD-intoxicated rats.

Results: The results revealed that the elevated serum marker enzymes and biochemical parameters in TCDD-treated rats were significantly reduced toward normal levels in saponin rich fraction of T. terrestris drug-treated animals when comparable to ethanolic extract of T. terrestris drug-treated group. The plant extracts have got a notable inhibitory activity on the formation of LPO products in the basal as well as in the presence of inducers.

Conclusion: The plant extracts hindered oxidative damage that occurred to the hepatocytes during TCDD toxicity may be responsible for the hepatoprotective activity in the present study.

Keywords: Ethanolic extract of T. terrestris, Hepatoprotective, Oxidative stress, Saponin rich fraction of T. terrestris, 2,3,7,8-Tetrachlorodibenzo-pdioxin.

(C) 2018 The Authors. Published by Innovare Academic Sciences Pvt Ltd. This is an open access article under the CC BY license (http://creativecommons. org/licenses/by/4. 0/) DOI: http://dx.doi.org/10.22159/ajpcr.2018.v11i6.24922

\section{INTRODUCTION}

A group of chemically related environmental pollutants called as dioxins are found throughout the world and get accumulated in the food products mainly meat, dairy products, fish, and shellfish. Among dioxins, the common and the most toxic xenobiotic environmental contaminant is 2,3,7,8-tetrachlorodibenzo-p-dioxin (TCDD) which belongs to halogenated polycyclic hydrocarbons [1]. It produces several types of toxic effects including dermal toxicity, immunotoxicity, hepatotoxicity, carcinogenicity, neurobehavioral, endocrine, metabolic, and teratogenic alterations [2]. It is demonstrated by recent studies that mice and rats exposed to different doses of TCDD lead to oxidative stress [3], through an increased production of reactive oxygen species (ROS), lipid peroxidation (LPO), and DNA damage [4].

At present, the researchers are focusing in searching potential herbal plants as antioxidants in reducing the tissue injury due to oxidative stress [5]. Endogenous antioxidant chemicals present in plants may play an important role in antioxidative defense, thereby protecting the biological functions of cells against the oxidative stress [6]. Tribulus terrestris L. belongs to the family Zygophyllaceae and the fruit is commonly known as "caltrops" or "devil's thorn," found throughout the world. In several countries, T. terrestris is traditionally used as astringent, diuretic, tonic, antihypertensive, aphrodisiac, analgesic, and urinary antiseptic [7]. In the cultures of India and Greece, historically, it was used as a rejuvenation tonic [8]. The present investigation is undertaken to screen the hepatoprotective and antioxidant properties of saponins rich butanol fraction of T. terrestris (SFTT) fruits. These activities of SFTT are compared with the crude ethanolic extract of T. terrestris (EETT) fruits.

\section{METHODS}

Collection of $T$. terrestris fruits

The T. terrestris ripe fruits were collected from Chennai. It was authenticated by Dr. Sankaranarayanan, Assistant Director, Department of Research and Development of Siddha Medical College and Research Center, India, and the herbarium file contains the voucher specimen of the same.

\section{Preparation of EETT and SFTT}

The fruits of T. terrestris (500 g) are dried, powdered, and extracted in ethanol by cold maceration with a yield of $10.56 \%(\mathrm{w} / \mathrm{w})$. The saponins isolation was carried out based on the method of Kostovaa et al. [9]. The yield of crude saponins extract was found to be $0.34 \%$ (w/w).

\section{Animals}

Adult Wister rats and adult albino mice were procured from the animal house in Vel's College of Pharmacy, Chennai, India, are used for the toxicological and pharmacological studies. The animals were maintained in the propylene cages with well-ventilated natural $12 \pm 1 \mathrm{~h}$ day-night cycle and room temperature. They were fed balanced rodent pellet diet from Poultry Research Station, Nandanam, Chennai, India, and water ad libitum was provided throughout the experimental period. The animals were sheltered for 1 week and before the experiment they were acclimatized to laboratory temperature. The protocol was approved by the Institutional Animal Ethics Committee constituted for the purpose as per CPCSEA Guidelines.

\section{Acute toxicity studies}

Acute toxicity studies were carried out using OECD 423 guidelines. The animals were carefully monitored for the toxicity signs or mortality due to the drug treatment and $\mathrm{LD}_{50}$ doses were determined. From the $\mathrm{LD}_{50}$ concentration, $1 / 10^{\text {th }}$ of the dose was considered for the evaluation of hepatoprotective activity. A further observation of drug-treated animals was done for 14 days to find the clinical symptoms and mortality.

Assay of hepatoprotective activity

The hepatoprotective activity of the EETT and SFTT extracts on TCDD-induced hepatic damage was studied according to the method 
of Fletcher et al. [10]. Wister albino rats were divided into six groups of six animals each. Group I served as control which received $0.5 \mathrm{ml}$ corn oil p.o. daily for 28 days. Group II served as negative control and received single dose of $40 \mu \mathrm{g} / \mathrm{kg}$ b.w. of TCDD in corn oil p.o. on the $7^{\text {th }}$ day. Group III: Animals were pretreated with EETT (200 mg/Kg b.w.) daily in corn oil for 1 week before the single dosing of TCDD ( $40 \mu \mathrm{g} / \mathrm{kg}$ b.w.) on the $7^{\text {th }}$ day and throughout the experimental period of 28 days. Group IV: Animals were pretreated with SFTT (100 mg/Kg b.w.) daily in corn oil for 1 week before the dosing of TCDD ( $40 \mu \mathrm{g} / \mathrm{kg}$ b.w.) on the $7^{\text {th }}$ day and throughout the experimental period 28 days. Group V: Animals were pretreated with standard drug silymarin (50 mg/Kg b.w.) daily in corn oil for 1 week before the dosing of TCDD and throughout the experiment. This group served as positive control.

On the $29^{\text {th }}$ day, the animals were given light ether anesthesia and sacrificed by cervical decapitation. The blood and liver tissue were dissected out for various estimations.

\section{Assay of liver marker enzymes and biochemical parameters}

The blood was allowed to clot at room temperature and centrifuged at $3000 \mathrm{rpm}$ for $10 \mathrm{~min}$ to separate the serum which is used to analyze various enzymatic and biochemical parameters. The assay of marker enzymes such as aspartate aminotransferase and alanine aminotransferase, alkaline phosphatase, lactate dehydrogenase, 5'nucleotidase, gamma-glutamyltransferase, and the biochemical parameters such as total protein, total cholesterol total bilirubin, triglycerides, and urea were estimated using the standard procedure protocol.

\section{LPO assay}

The liver was excised from the animals, washed in ice-cold saline and liver weight was calculated. Using Tris- $\mathrm{HCl}$ buffer $(0.1 \mathrm{M} \mathrm{pH} 7.4)$, a $10 \%$ liver homogenate was prepared and centrifuged. The liver supernatant was analyzed for the estimation of the LPO products such as malondialdehyde, conjugated dienes, and hydroperoxides by established protocols. The estimation of malondialdehyde in the presence of inducers such as ascorbate, ferrous sulfate, and hydrogen peroxide was also estimated. All the enzymatic, biochemical, and LPO product assays were performed using Shimadzu spectrophotometer, ultraviolet-1601 model at specific wavelength.

\section{Statistical analysis}

The values reported are mean \pm standard error. The statistical analysis was carried out using analysis of variance (ANOVA) followed by Dunnett's t-test. $\mathrm{p}<0.05$ was considered as statistically significant.

\section{RESULTS}

\section{Acute toxicity studies}

In the present investigation, acute toxicity was conducted and no toxicity was observed up to $2000 \mathrm{mg} / \mathrm{kg}$ body weight.

\section{Liver marker enzyme assay}

Fig. 1 shows the significantly increased liver marker enzyme levels in the serum of Group II TCDD-intoxicated animals. At the same time, these enzyme levels were decreased significantly $(p<0.01$ and $p<0.001)$ in EETT- and SFTT-treated animals (Groups III and IV). Among the two extracts, SFTT was effective in correcting these marker enzyme levels when compared with its crude extract EETT.

\section{Biochemical analysis}

A significant reduction in the liver weight serum levels of total protein, cholesterol, and triglyceride was shown in Groups III and IV drugtreated animals when compared to that of Group II TCDD-intoxicated rats (Table 1). Similarly, the urea and bilirubin levels were found to be significantly increased in Group II rats, and on EETT and SFTT treatment, these parameters were found to be normalized.

\section{LPO assay}

The levels of LPO products such as malondialdehyde, conjugated dienes (CDs), and hydroperoxides were significantly increased $(\mathrm{p}<0.001)$ in the liver tissues of TCDD-intoxicated Group II rats (Table 2). The increase in the LPO substances in the liver of TCDD-intoxicated rats may be because of the enhanced LPO due to the above free radicals, leading to liver tissue injury.

\section{DISCUSSION}

TCDD is a most potent environmental xenobiotic among many halogenated hydrocarbons. The toxic response is activated through the binding of TCDD to the aryl hydrocarbon receptor (AhR) as which, in turn, forms a heterodimer with AhR nuclear translocator and binds to DNA through specific sequences called dioxin responsive elements, leading to the alteration of CYP1A1 genes and trigger the oxidative stress and generation of free radicals [11]. Damage to the liver cells due to free radicals will make the liver marker enzymes as well as certain biochemical such as urea and bilirubin to leak into the bloodstream which, in turn, confirms the hepatic damage against their higher concentration in cytoplasm of liver cells [12]. The administration of plant extracts, especially saponin rich fraction of T. terrestris (SFTT), reduced the concentrations of these enzymes in serum. Saponins belong to steroid or triterpenoid glycosides which are present in many plants and used in human and animal nutrition as well therapeutic purposes including for the treatment of liver ailments [13]. Recently, Su et al. [14]

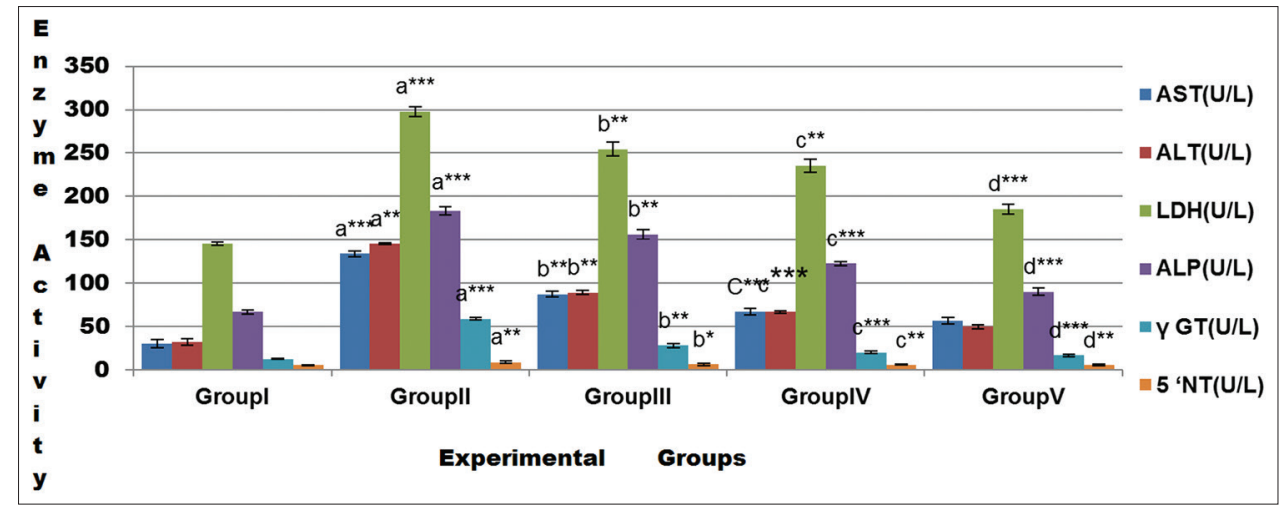

Fig. 1: The effect of ethanolic extract of Tribulus terrestris, Saponin rich fraction of $T$. terrestris, and silymarin on various liver marker enzymes in 2,3,7,8-tetrachlorodibenzo-p-dioxin-intoxicated rats. Values are mean \pm standard error of the mean rom six animals in each group. Statistically significant test for comparison was done by ANOVA, followed by Dunnett's t-test. Comparison between a - Group I versus Group II, b - Group II versus Group III, c - Group II versus Group IV, and d - Group II versus Group V. p values: ${ }^{*}<0.05, * *<0.01$, $* * *<0.001$, ns - non-significant 
Table 1: The effect of EETT, SFTT, and silymarin on various biochemical parameters in TCDD-intoxicated rats

\begin{tabular}{|c|c|c|c|c|c|c|}
\hline Treatment & $\begin{array}{l}\text { Liver weight } \\
\text { (mg/g bodyweight) }\end{array}$ & $\begin{array}{l}\text { Total protein } \\
\text { (g/dl) }\end{array}$ & $\begin{array}{l}\text { Total cholesterol } \\
\text { (mg/dl) }\end{array}$ & $\begin{array}{l}\text { Total bilirubin } \\
\text { (mg/dl) }\end{array}$ & Urea (mg/dl) & $\begin{array}{l}\text { Triglycerides } \\
\text { (mg/dl) }\end{array}$ \\
\hline Group-I (control) & $34.56 \pm 0.41$ & $6.92 \pm 2.12$ & $166.23 \pm 3.67$ & $0.45 \pm 0.21$ & $21.34 \pm 0.45$ & $133.45 \pm 1.45$ \\
\hline Group-II (TCDD treated) & $65.98 \pm 0.23 \mathrm{a}^{* * *}$ & $4.34 \pm 1.56 \mathrm{a}^{* *}$ & $129.60 \pm 2.56 a^{* *}$ & $2.17 \pm 0.45 \mathrm{a}^{* * *}$ & $47.00 \pm 1.34 \mathrm{a}^{* *}$ & $87.34 \pm 2.34 \mathrm{a}^{* *}$ \\
\hline $\begin{array}{l}\text { Group-III (TCDD+EETT) } \\
\text { (200 mg/kg b.w. treated) }\end{array}$ & $59.30 \pm 0.57 \mathrm{~b}^{*}$ & $5.89 \pm 2.10 b^{*}$ & $139.34 \pm 3.21 b^{*}$ & $1.23 \pm 0.32 \mathrm{~b}^{*}$ & $39.67 \pm 1.76 b^{*}$ & $127.90 \pm 1.56 b^{*}$ \\
\hline $\begin{array}{l}\text { Group-IV (TCDD+SFTT) } \\
\text { (100 mg/kg b.w. treated) }\end{array}$ & $49.69 \pm 1.37 c^{* *}$ & $6.46 \pm 2.45 \mathrm{c}^{* *}$ & $149.97 \pm 3.93 c^{* *}$ & $0.98 \pm 0.93 c^{* *}$ & $31.45 \pm 1.20 c^{* *}$ & $1130.00 \pm 2.56 c^{* *}$ \\
\hline
\end{tabular}

(50 mg/kg b.w. treated)

Values are mean \pm SEM from six animals in each group. Statistically significant test for comparison was done by ANOVA, followed by Dunnett's t-test. Comparison between a - Group I versus Group II, b - Group II versus Group III, c - Group II versus Group IV, and d - Group II versus Group V. P values: ${ }^{*}<0.05$, ${ }^{* *}<0.01, * * *<0.001$, ns - non-significant. EETT: Ethanolic extract of Tribulus terrestris, SFTT: Saponin rich fraction of Tribulus terrestris, TCDD: 2,3,7,8-Tetrachlorodibenzo-p-dioxin

Table 2: The effect of EETT, SFTT, and silymarin on various liver LPO products TCDD-intoxicated rats

\begin{tabular}{|c|c|c|c|c|c|c|}
\hline Treatment & $\begin{array}{l}\text { Basal LPO } \\
\text { (nanomoles of MDA } \\
\text { formed/mg tissue) }\end{array}$ & $\begin{array}{l}\text { Ascorbate-induced } \\
\text { LPO } \\
\text { (nanomoles of } \\
\text { MDA formed/mg } \\
\text { tissue) }\end{array}$ & $\begin{array}{l}\text { Peroxide-induced } \\
\text { LPO } \\
\text { (nanomoles of MDA } \\
\text { formed/mg tissue) }\end{array}$ & $\begin{array}{l}\text { Ferrous } \\
\text { sulfate-induced } \\
\text { LPO } \\
\text { (nanomoles of } \\
\text { MDA formed/mg } \\
\text { tissue) }\end{array}$ & $\begin{array}{l}\mathrm{CD} \Delta^{233} / \mathrm{mg} \text { of } \\
\text { protein }\end{array}$ & $\begin{array}{l}\text { Hydroperoxides } \\
\text { millimoles/mg } \\
\text { of protein }\end{array}$ \\
\hline $\begin{array}{l}\text { Group-I } \\
\text { (control) }\end{array}$ & $0.208 \pm 0.02$ & $0.221 \pm 0.03$ & $0.210 \pm 0.09$ & $0.213 \pm 0.29$ & $0.23 \pm 0.80$ & $156.56 \pm 13.78$ \\
\hline $\begin{array}{l}\text { Group-II } \\
\text { (TCDD treated) }\end{array}$ & $0.557 \pm 0.06 a^{* * *}$ & $0.610 \pm 0.02 \mathrm{a}^{* * *}$ & $0.567 \pm 0.02 \mathrm{a}^{* * *}$ & $0.461 \pm 0.12 a^{* * *}$ & $0.65 \pm 0.05 a^{* * *}$ & $369.45 \pm 17.60 a^{* * *}$ \\
\hline $\begin{array}{l}\text { Group-III } \\
\text { (TCDD+EETT) } \\
(200 \mathrm{mg} / \mathrm{kg} \text { b.w. } \\
\text { treated) }\end{array}$ & $0.280 \pm 0.02 b^{*}$ & $0.410 \pm 0.04 \mathrm{~b}^{*}$ & $0.323 \pm 0.06 b^{*}$ & $0.258 \pm 0.23 b^{* *}$ & $0.56 \pm 0.23 b^{*}$ & $243.00 \pm 23.00 b^{* *}$ \\
\hline $\begin{array}{l}\text { Group-IV } \\
\text { (TCDD+SFTT) } \\
\text { (100 mg/kg b.w. } \\
\text { treated) }\end{array}$ & $0.250 \pm 0.26 \mathrm{c}^{* *}$ & $0.233 \pm 0.03 c^{* *}$ & $0.287 \pm 0.05 c^{* *}$ & $0.228 \pm 0.09 \mathrm{c}^{* *}$ & $0.44 \pm 0.12 c^{* *}$ & $173.74 \pm 14.84 \mathrm{c}^{* * *}$ \\
\hline $\begin{array}{l}\text { Group } \\
\text { V (TCDD+silymarin) } \\
\text { (50 mg/kg b.w. } \\
\text { treated) }\end{array}$ & $0.212 \pm 0.01 \mathrm{~d}^{* *}$ & $0.218 \pm 0.21 \mathrm{~d}^{* *}$ & $0.214 \pm 0.03 \mathrm{~d}^{* *}$ & $0.196 \pm 0.17 d^{* * *}$ & $0.46 \pm 0.23 \mathrm{~d}^{* *}$ & $168.00 \pm 19.00 \mathrm{~d}^{* * *}$ \\
\hline
\end{tabular}

Values are mean \pm SEM from six animals in each group. Statistically significant test for comparison was done by ANOVA, followed by Dunnett's t-test. Comparison

between a - Group I versus Group II, b - Group II versus Group III, c - Group II versus Group IV, and d - Group II versus Group V. P values: *<0.05, ${ }^{* *}<0.01$,

***<0.001, ns - non-significant. EETT: Ethanolic extract of Tribulus terrestris, SFTT: Saponin rich fraction of Tribulus terrestris, LPO: Lipid peroxidation,

TCDD: 2,3,7,8-Tetrachlorodibenzo-p-dioxin, MDA: Malondialdehyde, CD: Conjugated dienes

have isolated and characterized five new steroidal saponins were isolated from the fruits of T. terrestris. The cumulative effect of these saponins may account for the pronounced hepatoprotective activity of the SFTT extract in the present study.

TCDD exposure leads to LPO followed by ROS production, leading to membrane damage which disrupts the functional integrity of hepatocytes [15]. Rhee et al. [16] have stated that prooxidant reactions could be quantified by measuring the process known as LPO which measures the oxidation of membrane phospholipids and will be expressed in terms of $\mathrm{CD}$ and thiobarbituric acid reactive substances. According to Abuja and Albertini [17] in the liver homogenate, LPO can occur at in vitro conditions without the involvement of enzymes and in the presence of inducers such as ascorbate, $\mathrm{Fe}^{2+} / \mathrm{Fe}^{3+}$, and $\mathrm{H}_{2} \mathrm{O}_{2}$. In the present investigation, a significant reduction in malondialdehyde level is observed by the plant extracts. To clarify the mode of action of plant extracts, the in vitro LPO experiments were carried out using the LPO inducers such as ascorbic acid, $\mathrm{FeSO}_{4}$, and $\mathrm{H}_{2} \mathrm{O}_{2}$. In the present study, the plant extracts were effective in reducing the production of these LPO products both in vivo and in vitro. According to Xuy et al. [18], saponins such as ruscogin, hecogenin, gitogenin, diosgening, glucopyranosyl, and yamogenin are chemically belonged steroid or triterpenoid glycosides contain many ring structures with reducing capability have the potential to react with the free radicals and reducing the LPO observed in the present study.

\section{CONCLUSION}

Through the phytochemical components, the SFTT extract could trap the free radicals produced by the microsomal enzymes in TCDD metabolism, thereby hinder their interaction with polyunsaturated fatty acids to initiate the lipid peroxidative processes. Thus, from the foregoing findings, it was observed that saponin fraction of the T. terrestris is a promising hepatoprotective agent and this activity may be due to its antioxidant chemicals present in it. Work is in progress here to identify the antioxidant ability of this plant extract.

\section{AUTHORS' CONTRIBUTION}

Both the authors, the Rajeswary Hari and Muralidharan, contributed equally in the designing and execution of the above experiment.

\section{REFERENCES}

1. Halwachs S, Lakoma C, Gebhardt R, Schäfer I, Seibel P, Honscha W, et al. Dioxin mediates downregulation of the reduced folate carrier transport activity via the arylhydrocarbon receptor signalling pathway. 
Toxicol Appl Pharmacol 2010;246:100-6

2. Hung YC, Huang GS, Sava VM, Blagodarsky VA, Hong MY. Protective effects of tea melanin against 2,3,7,8-tetrachlorodibenzo-p-dioxininduced toxicity: Antioxidant activity and aryl hydrocarbon receptor suppressive effect. Biol Pharma Bull 2006;29:2284-91.

3. Slezak BP, Hatch GE, DeVito MJ, Diliberto JJ, Slade R, Crissman K, et al. Oxidative stress in female $\mathrm{B} 6 \mathrm{C} 3 \mathrm{~F} 1$ mice following acute and subchronic exposure to 2,3,7,8-tetrachlorodibenzo-p-dioxin (TCDD). Toxicol Sci 2000;54:390-8.

4. Singh P, Singh RL, Kakkar P. Antioxidant, DNA damage protective and hepatoprotective activities of Amorphophallus campanulatusint. J Pharm Pharm Sci 2016;8:330-8.

5. Vasuki R, Hari R, Arumugam SP. Hepatoprotective action of ethanolic extracts of Eclipta alba and Piper longum Linn and their combination

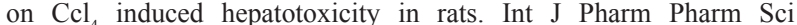
2012;4:455-9

6. Naito M, Hayashi T, Iguchi A. New approaches to the prevention of atherosclerosis. Drugs 1995;50:440-53.

7. Kumar A. Comparative and Quantitative determination of Quercetin and other flavonoids in north Indian populations of Tribulus terrestris by HPLC. Int J Pharma Bio Sci 2012;3:69-79.

8. Adaikan PG, Gauthaman K, Prasad RN, Ng SC. Pro erectile pharmacological effects of Tribulus terrestris extract on the rabbit corpus cavernosum. Ann Acad Med Singapore 2000;29:22-6.

9. Kostovaa I, Dincheva D, Rentschb GH, Dimitrovb V, Ivanovaa A. Two new sulfated furostanol Saponins from Tribulus terrestris. Natur Forsch
C 2002;57:33-8

10. Fletcher N, Hanberg A, Hakansson H. Hepatic vitamin A depletion is a sensitive marker of 2,3,7,8-tetrachlorodibenzo-p-dioxin (TCDD) exposure in four rodent species. Toxicol Sci 2001;62:166-75.

11. Schmidt JV, Bradfield CA. Ah receptor signaling pathways. Annu Rev Cell Dev Biol 1996;12:55-89.

12. Valko M, Rhodes CJ, Moncol J, Izakovic M, Mazur M. Free radicals, metals and antioxidants in oxidative stress induced cancer. Chem Biol Interact 2006; 18:31-5

13. Huang QF, Zhang SJ, Zheng L, He M, Huang RB, Lin X. Hepatoprotective effects of total Saponins isolated from Taraphochlamys affinis against carbon tetrachloride induced liver injury in rats. Food Chem Toxicol 2012;50:713-8.

14. Su L, Chen G, Feng S, Wang W, Li Z, et al. Steroidal saponins from Tribulus terrestris. Steroids 2009;74:399-403.

15. Shertzer HG, Nebert DW, Puga A, Ary M, Sonntag D, Dixon K, et al. Dioxin causes a sustained oxidative stress response in the mouse. Biochem Biophys Res Commun 1998;253:44-8.

16. Rhee GS, Chang TS, Bae YS, Lee SR, Kang SW. Cellular regulation by hydrogen peroxide. J Am Soc Nephrol 2003;14:211.

17. Abuja PM, Albertini R. Methods for monitoring oxidative stress, lipid peroxidation and oxidation resistance of lipoproteins. Clin Chim Acta 2001;306:1

18. Xuy X, Chen HS, Liamg HQ, Gu ZB, Lui WY, Leung WN, et al. Three new saponins from Tribulus terrestris. Planta Med 2001;66:545-50. 